\title{
PENGARUH PEMBERLAKUAN WAJIB SNI BATERAI PRIMER TERHADAP IMPOR PRODUK BATERAI PRIMER INDONESIA
}

\author{
Influence of the Enforcement of Mandatory SNI for Primary Batteries on the Import of \\ Indonesia Primer Battery Products
}

\author{
Danar A. Susanto dan Ellia Kristiningrum \\ Pusat Riset dan Pengembangan Sumber Daya Manusia, Badan Standardisasi Nasional \\ Gedung I BPPT Lantai 12, Jalan M.H. Thamrin No. 8, Jakarta, Indonesia \\ e-mail: danar@bsn.go.id
}

Diterima: 21 November 2018, Direvisi: 28 Januari 2019, Disetujui: 8 Maret 2019

\begin{abstract}
Abstrak
Pemberlakuan Standar Nasional Indonesia (SNI) baterai primer secara wajib dimulai pada akhir tahun 2009 dengan di tetapkanya Keputusan Menteri Perindustrian Nomor No.36/M-IND/Per/3/2009 sebagaimana sudah diubah dalam Keputusan Menteri Perindustrian Nomor No.101/M-IND/PER/10/2009. Salah satu tujuan peraturan ini adalah untuk meningkatkan daya saing produk baterai primer dalam negeri, sehingga ketergantungan akan produk impor dapat berkurang. Penelitian ini membahas pengaruh pemberlakuan wajib SNI baterai primer terhadap impor produk baterai primer Indonesia dengan metode analisis ekonometrika menggunakan deret waktu pada periode 20042015. Variabel terikat yang digunakan adalah jumlah impor baterai primer, sedangkan variabel bebasnya adalah PDB riil, kurs riil dan dummy pemberlakuan wajib SNI baterai primer. Hasil penelitian menunjukkan bahwa pemberlakuan wajib SNI baterai primer secara parsial tidak berpengaruh signifikan terhadap nilai impor baterai primer. Namun secara simultan dengan variabel nilai tukar, penerapan SNI berpengaruh signifikan secara positif. Sedangkan secara simultan dengan variabel PDB, variabel penerapan SNI berpengaruh signifikan secara negatif terhadap nilai impor baterai primer.
\end{abstract}

Kata kunci: baterai primer, impor baterai primer, pemberlakuan wajib SNI

\section{Abstract}

The enforcement of the Mandatory Indonesian National Standard (SNI) of primary batteries shall commence at the end of 2009 with the stipulation of the Decree of the Minister of Industry Number. 36/M-IND/Per/3/2009 as amended in Decree of the Minister of Industry Number No.101 / M-IND / PER / 10/2009. One of the objectives of this regulation is to improve the competitiveness of national primary battery products, so that the dependence on imported products can be reduced. This study discusses the effect of mandatory application of primary battery SNI on the import of Indonesian primary battery products with econometric analysis method using time series in the period 2004-2015. The dependent variable used is the number of primary battery imports, while the independent variables are real GDP, the real exchange rate and the dummy of the mandatory application of SNI for primary battery. The results of the study show that the mandatory application of primary battery SNI partially does not have a significant effect on the import value of primary batteries. But simultaneously with variable exchange rates, the application of SNI has a positive significant effect. Whereas simultaneously with the GDP variable, the variable of SNI implementation has a significant negative effect on the import value of primary batteries.

Keyword: enforcement of mandatory SNI, import of primary battery, primary battery,

\section{PENDAHULUAN}

Standar secara umum diartikan sebagai konstruksi yang dihasilkan dari alasan, pilihan kolektif dan kesepakatan pada solusi masalah yang berulang. Dilihat dengan cara ini, standar dilihat sebagai keseimbangan antara persyaratan pengguna, kemungkinan teknologi dan biaya terkait produsen, dan pembatasan yang diberlakukan oleh pemerintah untuk kepentingan masyarakat pada umumnya. Secara fungsional, standar industri diartikan sebagai satu set dimana semua elemen produk, proses, atau prosedur harus sesuai dengan persyaratannya. Proses standardisasi pada prinsipnya mengejar kesesuaian terhadap persyaratan dengan tujuan untuk meningkatkan efisiensi kegiatan ekonomi (Tassey, 2000).

Bagi pembuat kebijakan, keberadaan standar yang dihasilkan dari proses standardisasi memainkan peran penting dalam mencapai liberalisasi perdagangan internasional (Blind \& Mangelsdorf, 2016). Standar yang muncul sebagai hasil dari proses yang sangat rumit, dikembangkan oleh komite-komite teknis dari organisasi pengembang standar (Standards Developing 
Organizations/SDO), menjadi sarana penting untuk ekonomi suatu negara (Freimuth, Oelmann, \& Amann, 2018). Dengan adanya bukti-bukti ilmiah mengenai dampak dari standardisasi pada pertumbuhan, para pengambil kebijakan di beberapa negara industri menyadari pentingnya standardisasi untuk daya saing ekonomi mereka (Blind \& Mangelsdorf, 2016).

Baterai adalah perangkat yang berfungsi untuk mengkonversi energi kimia menjadi energi listrik melalui reaksi elektrokimia reduksi dan oksidasi. Dikenal dua klasifikasi baterai, yaitu baterai primer yang hanya dapat digunakan satu kali, dan baterai sekunder, yang dapat digunakan berkali-kali karena dapat diisi ulang (Satriady, Alamsyah, Saad, \& Hidayat, 2016). Baterai primer umumnya memberikan tegangan 1,5 Volt dan terdiri dari berbagai jenis ukuran seperti AAA, AA, C, D. Disamping itu, terdapat juga baterai primer yang berbentuk kotak dengan tegangan 6 Volt dan 9 Volt. Jenis baterai primer ini bermacam-macam, atara lain baterai zinc-carbon, baterai alkali, baterai lithium, baterai silver oxide (Kho, 2015).

Standar yang berlaku secara nasional di Indonasia adalah Standar Nasional Indonesia (SNI) yang ditetapkan oleh Badan Standardisasi Nasional. Persyaratan kualitas produk baterai primer diatur dalam SNI 04-2051.1-2004 (Baterai primer - bagian 1: umum) dan SNI 04-2051.22004 (Baterai primer-bagian 2: spesifikasi fisik dan listrik). Banyaknya peredaran produk baterai primer di pasar yang diikuti dengan meningkatnya nilai impor, menjadikan pemerintah mengambil tindakan dengan memberlakukan secara wajib kedua SNI tersebut melalui Keputusan Menteri Perindustrian Nomor 36/M-IND/PER/3/2009 yang kemudian direvisi menjadi Keputusan Menteri Perindustrian Nomor 101/M-IND/PER/10/2009. Tujuan pemberlakuan wajib SNI baterai primer adalah untuk menjamin mutu produk industri, mencapai daya guna produksi dan melindungi konsumen terhadap mutu produk, serta menciptakan persaingan usaha yang sehat (Kementerian Perindustrian, 2009b).

Salah satu tujuan peraturan ini adalah untuk meningkatkan daya guna industri atau daya saing produk baterai primer dalam negeri, sehingga ketergantungan akan produk impor dapat berkurang. Penerapan SNI wajib ini diharapkan dapat mencegah beredarnya produkproduk yang tidak bermutu (tidak bersertifkat SNI) di pasar domestik, baik yang berasal dari dalam negeri maupun produk impor. Penelitian ini bertujuan untuk menganalisis pengaruh pemberlakuan SNI baterai primer secara wajib oleh pemerintah terhadap impor produk baterei primer Indonesia.

\section{TINJAUAN PUSTAKA}

\subsection{Regulasi Teknis Pemberlakuan Wajib SNI Baterai Primer}

Pemberlakuan SNI Baterai Primer secara wajib, didasari dengan Peraturan Menteri Perindustrian Nomor 101/M-IND/PER/10/2009 tentang Perubahan Atas Menteri Perindustrian Nomor 36/M-IND/PER/3/2009 tentang Pemberlakukan Standar Nasional Indonesia (SNI) Baterai Primer Secara Wajib. Peraturan ini mewajibkan kepada seluruh perusahaan industri yang memproduksi atau mengimpor baterai primer yang diedarkan di wilayah Negara Kesatuan Republik Indonesia (NKRI) wajib untuk menerapkan dan memiliki SPPT SNI Baterai Primer, dan membubuhkan tanda SNI pada setiap produk. Ruang lingkup pemberlakuan Peraturan Menteri Perindustrian Republik Indonesia Nomor 101/MIND/PER/10/2010 adalah baterai primer yang terdiri dari satu atau lebih sel primer, termasuk wadah, terminal dan penandaan. Pos tarif padan Harmonized Systems (HS) yang masuk dalam regulasi teknis ini disajikan pada Tabel 1.

Tabel 1 Pos tarif produk baterai primer.

\begin{tabular}{|c|c|c|c|}
\hline No & Nomor SNI & Judul SNI & Pos Tarif (Harmonized System/HS) \\
\hline 1. & $\begin{array}{l}\text { SNI 04-2051.1- } \\
2004\end{array}$ & $\begin{array}{l}\text { Baterai Primer - } \\
\text { Bagian } 1 \text { : Umum }\end{array}$ & $\begin{aligned} 8506.10 .10 .00: & \text { Baterai primer mangan dioksida: } \\
& \text { mempunyai volume bagian luar tidak } \\
& \text { melebihi } 300 \mathrm{~cm}^{3}\end{aligned}$ \\
\hline 2. & $\begin{array}{l}\text { SNI 04-2051.2- } \\
2004\end{array}$ & $\begin{array}{l}\text { Baterai Primer - } \\
\text { Bagian } 2 \text { : Spesifikasi } \\
\text { Fisik dan Listrik }\end{array}$ & $\begin{array}{l}\text { 8506.50.00.00 : Baterai primer mangan dioksida : lain-lain } \\
\text { 8506.50.00.00: Lithium } \\
\text { 8506.80.10.00 : Seng karbon : mempunyai volume bagian } \\
\text { luar tidak melebihi } 300 \mathrm{~cm}^{3} \\
\text { 8506.80.20.00 : Seng karbon : mempunyai volume bagian } \\
\text { luar melebihi } 300 \mathrm{~cm}^{3}\end{array}$ \\
\hline
\end{tabular}

Sumber: Kementerian Perindustrian (2009b).

\subsection{SNI Baterai Primer}

Baterai primer adalah baterai yang terdiri dari satu atau lebih sel primer, termasuk pembungkus/ kotak, terminal dan penandaan (Badan Standardisasi Nasional, 2004). Berdasarkan kemampuannya untuk dikosongkan (discharged) 
dan diisi ulang (recharged) baterai dibagi menjadi dua jenis yaitu baterai primer dan baterai sekunder. Sesuai dengan Peraturan Menteri Perindustrian Nomor 101/M-IND/PER/10/2010, SNI yang diwajibkan adalah SNI 04-2051.1-2004 dan SNI 04-2051.2-2004.

\section{a. SNI 04-2051.1-2004}

Standar ini merupakan standar berseri sebagai adopsi IEC 60086-1:2000, Primary batteries - part 1: general yang disusun oleh Panitia teknis bisnis elektronika dan panitia teknis elektronika untuk keperluan rumah tangga. Standar ini dibahas melalui rapat-rapat teknis, pra konsensus dan terakhir dibahas dalam rapat konsensus oleh stakeholder. Persyaratan baterai primer yang diatur dalam standar ini mencakup persyaratan umum, yang meliputi desain, dimensi baterai, terminal, klasifikasi (sistem elektronika), peruntukan, penandaan, mampu tukar: tegangan baterai. Selain persyaratan umum, standar ini juga mengatur tentang kinerja yang mencakup kinerja discharge, kestabilan dimensi, kebocoran, batas tegangan sirkuit terbuka, keluaran layanan, dan keselamatan.

\section{b. SNI 04-2051.2-2004}

Standar ini berlaku untuk baterai primer berdasarkan pada sistem elektrokimia yang distandarkan, mencakup dimensi fisik dan kondisi uji luah (discharge) dan persyaratan kinerja luah. SNI ini merupakan hasil adopsi IEC 60086-2:2000, primary batteries - part 2: physical and electrical spesifications. Definisi baterai primer dalam standar ini adalah baterai yang memiliki satu atau lebih sel primer, meliputi wadah, terminal dan penandaan.

\subsection{Free Trade Agreement (FTA)}

Perdagangan bebas antar negara ditunjukkan dengan tarif bea masuk yang relatif rendah. Rendahnya tarif bea masuk tersebut yang mendorong peningkatan impor Indonesia. Peningkatan importasi ini mengakibatkan adanya persaingan produk impor dan produk dalam negeri, sehingga diperlukan daya saing produk dalam negeri untuk dapat menguasai pasar (Kementerian Perdagangan, 2011). Teori FTA diterima karena keuntungan yang diperoleh negara-negara yang terlibat dari perdagangan ini (Widyasanti, 2010). Perjanjian ini melibatkan dua negara atau lebih dengan tujuan liberalisasi perdagangan barang dan jasa serta akses ke investasi antar negara dengan menghilangkan beberapa macam hambatan perdagangan, seperti menghilangkan sebagian besar (tidak semua) tarif dan menghapus kuota pada barang-barang yang dapat diekspor atau diimpor (Kementerian Perdagangan, 2015).

Manfaat ekonomi yang ditimbulkan oleh FTA yaitu meningkatnya akses pasar dan surplus ekonomi secara keseluruhan, terpenuhinya bahan baku, bahan penolong, barang modal, peningkatan investasi yang akan mempengaruhi struktur industri, mendorong adanya peningkatan kapasitas untuk peningkatan daya saing industri domestik, dan peningkatan daya beli masyarakat (Widyasanti, 2010). Gambar di bawah ini menggambarkan bahwa FTA telah menurunkan jumlah rata-rata tarif di dunia dari di atas $8 \%$ pada tahun 2010 menjadi 4\% pada tahun 2014.

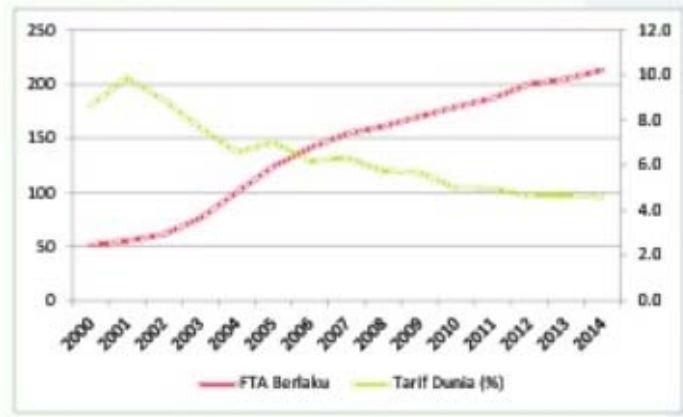

Gambar 1 FTA berlaku dan tarif dunia tahun 2000 $-2014$

Sumber: World Bank\&ARIC FTA Databased 2015 dalam Kementerian Perdagangan (2015).

Indonesia adalah salah satu negara yang cukup aktif dalam menyelesaikan perjanjian perdagangan bebas. Pada Juli 2012, Indonesia memiliki delapan FTA yang berlaku, enam regional dan dua bilateral (khusus, kawasan perdagangan bebas ASEAN, AFTA; ASEAN-Australia dan Selandia Baru, ASEAN-Cina, ASEAN-India, ASEAN-Jepang dan ASEAN-Korea FTAs, Indonesia-Jepang EPA dan Indonesia-Pakistan FTA). Perjanjian ini berarti bahwa Indonesia memiliki FTA dengan mitra dagang yang mencapai 67 persen dari total perdagangannya. Untuk konteks Chili, Peru, dan Meksiko memiliki rasio cakupan FTA lebih dari 80 persen, sementara Kanada, Singapura, dan Selandia Baru berada di lebih dari 50 persen (Ing, 2015).

Perdagangan luar negeri terdiri dari ekspor dan impor barang-barang. Ekspor merupakan penjualan barang dan jasa dari suatu negara ke negara lain, sedangkan impor adalah masuknya barang dan jasa ke suatu negara dari negara lain (Prakosa, 2012). Analisis impor seharusnya mendapatkan porsi yang seimbang dengan analisis ekspor yang sering dilakukan oleh para ahli, karena impor mencerminkan kedaulatan ekonomi suatu negara, apakah barang dan jasa buatan dalam negeri masih menjadi tuan rumah di negara sendiri (Atmadji, 2009).

\section{$2.4 \quad$ Nilai Tukar}

Nilai tukar merupakan harga dari satu mata uang dalam bentuk mata uang luar negeri. Nilai tukar mata uang ini dapat mempengaruhi perekonomian jika mengalami apresiasi atau depresiasi. Nilai 
tukar mata uang terhadap profitabilitas bank menggambarkan apabila mata uang mengalami apresiasi atau depresiasi maka akan berdampak profit bank (Dwijayanthy \& Naomi, 2010).

Nilai tukar mata uang yang sering disebut dengan kurs adalah harga satu unit mata uang asing dalam mata uang domestik atau dapat juga dikatakan harga mata uang domestik terhadap mata uang asing. Apabila nilai tukar didefinisikan sebagai nilai Rupiah dalam valuta asing dapat diformulasikan sebagai berikut:

$\mathrm{NT}$ IDR/USD = Rupiah yang diperlukan untuk membeli 1 dolar Amerika (USD)

$\mathrm{NT}$ IDR/YEN = Rupiah yang diperlukan untuk membeli satu Yen Jepang.

Dalam hal ini, apabila NT meningkat maka berarti Rupiah mengalami depresiasi, sedangkan apabila NT menurun maka Rupiah mengalami apresiasi. (Simorangkir \& Suseno, 2004).

\subsection{Produk Domestik Bruto (PDB)}

Produk Domestik Bruto (PDB) menjadi indikator penting untuk mengetahui perkembangan perekonomian suatu negara. (Bank Indonesia, 2016). PDB merupakan pendapatan suatu negara yang terdiri dari jumlah konsumsi, investasi, belanja pemerintah dan ekspor bersih (Prakosa, 2012). PDB ada dua jenis, yaitu:

- PDB riil/harga tetap yang diartikan sebagai harga barang dan jasa yang diproduksi suatu negara dalam waktu tertentu dan dinilai berdasarkan harga yang berlaku pada satu waktu yang telah ditentukan.

- PDB nominal/harga berlaku, yaitu nilai harga barang dan jasa yang diproduksi suatu negara dalam waktu tertentu dan dinilai berdasarkan harga yang berlaku pada waktu saat dilakukan penilaian (McEachern, 2000).

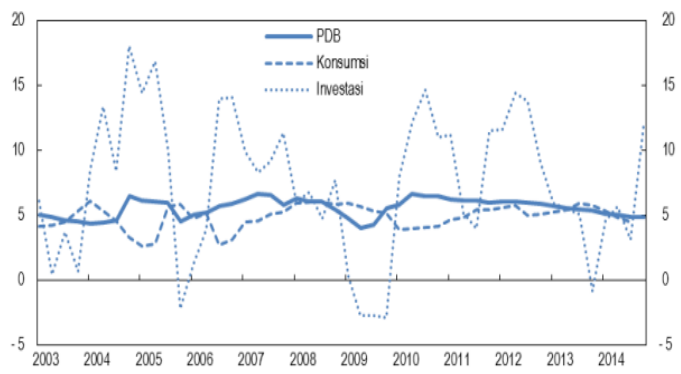

Gambar 2 Pertumbuhan PDB riil, konsumsi dan investasi Indonesia (OECD, 2015).

Perekonomian Indonesia telah mengalami banyak gejolak, pada tahun 2013, pertumbuhan PDB turun menjadi di bawah $6 \%$ untuk pertama kalinya sejak krisis keuangan global dan selama tahun 2014 pertumbuhan masih melambat. Meskipun dengan adanya perlambatan tersebut, pertumbuhan ekonomi Indonesia telah melampaui negara-negara lain di ASEAN. Investasi juga melemah pada tahun 2013-2014 yang diakibatkan oleh penurunan investasi dalam mesin dan alat transportasi (OECD, 2015).

\subsection{Impor}

Kegiatan impor dilakukan pemerintah untuk mencukupi kebutuhan konsumen. Menurut Undang-undang perpajakan, impor merupakan kegiatan atau aktivitas memasukkan barang dari luar wilayah pabean Indonesia (luar negeri) ke dalam wilayah pabean Indonesia. Sisi baik dari besarnya nilai impor adalah ketersediaannya kebutuhan rakyat negara itu akan produk atau jasa tertentu, namun sisi lainnya bisa mematikan produk dan jasa sejenis dalam negeri, dan yang paling mendasar menguras devisa negara yang bersangkutan (Christianto, 2013).

Realisasi impor tergantung pada kemampuan masyarakat untuk membeli produk buatan luar negeri. Semakin tinggi tingkat pendapatan, serta semakin rendah kemampuan negara menghasilkan barang, maka impor semakin banyak dan semakin banyak terdapat "kebocoran" dalam pendapatan nasional (Prakosa, 2012).

\subsection{Ekonometrika}

Ekonometrika adalah merupakan cabang dari ilmu ekonomi dengan menggunakan dan menerapkan matematika dan statistika untuk memecahkan masalah-masalah ekonomi yang dibuat dalam suatu model ekonometrik yang kemudian diestimasi hasilnya dan diuji lagi kesesuaiannya dengan teori ekonomi yang sudah ada. Pembentukan model ekonometrika berdasarkan teori ekonomi yang melandasinya (Sugiyanto, 2007).

Konsep dasar dari ilmu ekonometrik adalah mengkaji beberapa teori ekonomi sebelumnya dengan melakukan suatu analisis yang dapat dipertanggungjawabkan melalui matematika dan statistika. Tujuannya adalah untuk mengetahui teori ekonomi yang ada benarbenar dapat diaplikasikan pada suatu kasus tertentu atau pada suatu wilayah tertentu (Handayani, 2013).

Salah satu metode dalam ekonometrika untuk menilai suatu pengaruh variabel adalah menggunakan model Ordinary Least Square (OLS) yang merupakan model regresi dengan cara meminimalkan jumlah kuadrat kesalahan setiap observasi. Model dasar OLS bersumber dari model permintaan impor agregat Murray-Ginman dalam (Prakosa, 2012).

$$
\begin{gathered}
\text { Ln Yt }=\beta 0+\beta 1 \text { Ln PMt }+\beta 2 \text { Ln GDPt } \\
+\beta 3 \text { Ln XRt }+\varepsilon \ldots \ldots \ldots \text {. Persamaan } 1 .
\end{gathered}
$$




\begin{tabular}{|c|c|}
\hline Keterangan & \\
\hline $\operatorname{Ln} Y$ & $\begin{array}{l}\text { Logaritma natural jumlah } \\
\text { impor agregat }\end{array}$ \\
\hline Ln PM & $\begin{array}{l}\text { Logaritma natural harga } \\
\text { relatif }\end{array}$ \\
\hline Ln GDP & Logaritma natural PDB \\
\hline $\operatorname{Ln} X R$ & $\begin{array}{l}\text { Logaritma natural nilai } \\
\text { tukar }\end{array}$ \\
\hline$\beta 0, \beta 1, \beta 2, \beta 3$ & : Koefisien \\
\hline $\mathrm{t}$ & $\begin{array}{ll}\text { : } & \text { Indeks waktu } \\
\text { Error }\end{array}$ \\
\hline$\varepsilon$ & EIIUI \\
\hline
\end{tabular}

\section{METODE PENELITIAN}

Metode penelitian yang digunakan dalam penelitian ini adalah menggunakan model ekonometrika. Ekonometrika adalah suatu ilmu yang menerapkan teori ekonomi, matematika ekonomi, dan statistika ekonomi untuk memberikan dukungan empiris dari model yang dibangun oleh teori ekonomi dan untuk memberikan hasil dalam angka (D. N. Gujarati, 2004). Model ekonometrika menghubungkan peubah-peubah ekonomi dari suatu fenomena ekonomi yang mencakup unsur stokastik (Intriligator, 1978). Pengumpulan dan sumber data penelitian yang meliputi data nilai tukar mata uang, PDB dan impor baterai primer diperoleh dari Badan Pusat Statistik (BPS) dan Trade Map dengan deret waktu triwulanan. Variabel-variabel yang digunakan dalam penelitian ini disajikan pada Tabel 2.

Tabel 2 Variabel penelitian.

\begin{tabular}{|c|c|c|}
\hline No & Variabel & Satuan \\
\hline 1. & $\begin{array}{l}\text { Impor baterai } \\
\text { primer }\end{array}$ & US\$ \\
\hline 2. & Nilai tukar rupiah & Rp./US\$ \\
\hline 3. & PDB & Milyar Rp. \\
\hline 4. & $\begin{array}{l}\text { Penerapan SNI } \\
\text { (variabel dummy) }\end{array}$ & $\begin{array}{l}0=\text { Belum penerapan } \\
\text { wajib SNI } \\
1=\text { Sudah penerapan } \\
\text { wajib SNI }\end{array}$ \\
\hline
\end{tabular}

Pengolahan dan analisis data menggunakan software Eviews (Econometric Views) versi 7 dengan model Ordinary Least Square (OLS) yang merupakan model regresi dengan cara meminimalkan jumlah kuadrat kesalahan setiap observasi. Model pada persamaan 1, kemudian dimodifikaksi dengan menambahkan variabel dummy pemberlakuan wajib SNI baterai primer, sehingga diperoleh model penelitian sebagai berikut:

$$
\begin{aligned}
& \text { Log Yt }=\beta 0+\beta 1 \log X A t+\beta 2 \operatorname{LogXBt}+ \\
& \beta 3(\mathrm{DSNI} * \log \mathrm{XAt})+\beta 4(\mathrm{DSNI} * \operatorname{LogXBt})+ \\
& \beta 4 \mathrm{Yt}(-1)+\beta 5 \mathrm{DSNI}+\varepsilon \\
& \begin{array}{l}
\text { Keterangan : } \\
\text { Log } \mathrm{Y} \quad: \begin{array}{l}
\text { Logaritma impor baterai } \\
\text { primer }
\end{array}
\end{array}
\end{aligned}
$$

$$
\begin{aligned}
& \text { Log XA : Logaritma nilai tukar } \\
& \text { rupiah } \\
& \text { Log XB : Logaritma natural PDB } \\
& \mathrm{DSNI}^{*} \log \mathrm{XA} \quad \text { : Dummy interaksi } \\
& \text { pemberlakuan wajib SNI } \\
& \text { baterai primer dengan } \\
& \text { Logaritma nilai tukar } \\
& \text { rupiah } \\
& \mathrm{DSNI}^{*} \log \mathrm{XB} \quad \text { : Dummy interaksi } \\
& \text { pemberlakuan wajib SNI } \\
& \text { baterai primer dengan } \\
& \text { Logaritma nilai PDB } \\
& Y(-1) \quad: \text { Lag impor } \\
& \text { DSNI : Pemberlakuan wajib SNI } \\
& \beta 0, \beta 1, \beta 2, \beta 3 \text { : Koefisien } \\
& \mathrm{t} \quad: \text { Indeks waktu } \\
& \varepsilon
\end{aligned}
$$

\section{HASIL DAN PEMBAHASAN}

\subsection{Fungsi PDB riil terhadap jumlah impor baterai}

Nilai perdagangan impor suatu negara dapat dipengaruhi oleh perkembangan PDB. Hubungan antara PDB dan dan impor adalah hubungan linier, semakin besar PDB suatu negara, maka semakin besar pula impor yang dilakukan negara tersebut, demikian pula sebaliknya. Hubungan ini berkaitan langsung dan berpengaruh terhadap tingkat kesejahteraan dan selera masyarakat suatu negara (Prakosa, 2012).

Berdasarkan Gambar 3, PDB riil memiliki tren kenaikan sebesar $25 \%$ dari tahun 2004 sampai dengan tahun 2015 dengan kenaikan signifikan pada tahun 2011. Sedangkan impor baterai primer juga mempunyai tren kenaikan linier sebesar 43\% dari tahun 2004 sampai dengan tahun 2011, dengan kenaikan signifikan pada tahun 2010. Namun mengalami penurunan yang cukup drastis pada tahun 2011. Hubungan antara PDB riil dengan impor baterai primer adalah samasama memiliki tren kenaikan linier. Hal ini sesuai dengan penelitian dari Mardianto \& Kusumajaya (2014), Setiyaningsih (2014) dan Faisol (2017), bahwa PDB secara simultan dan signifikan berpengaruh terhadap impor suatu produk.

\subsection{Fungsi kurs riil terhadap jumlah impor baterai primer}

Nilai suatu mata uang terhadap mata uang negara lain (depresiasi dan apresiasi) akan mempengaruhi dan berdampak pada kegiatan perdagangan ekspor dan impor (Ginting, 2013). Nilai mata uang berfluktuasisasi setiap saat yang disebabkan oleh permintaan dan penawaran mata uang tersebut yang akan digunakan oleh pemerintah, dunia usaha, lembaga keuangan, individu dan lain-lain untuk alat transaksi, aset cadangan dan untuk spekulasi. Apabila mata uang 
terdepresiasi, maka nilai ekspor akan naik dan nilai impor akan turun (Prakosa, 2012). Pelemahan nilai tukar mata uang mengakibatkan naiknya hargaharga produk dipasaran, khususnya barang impor. Harga produk yang naik akan menurunkan daya beli konsumen untuk membeli suatu barang (Ginting, 2013). Harga produk impor yang naik akan menurunkan permintaan impor yang selanjutnya volume impor juga akan menurun (Husman, 2005).

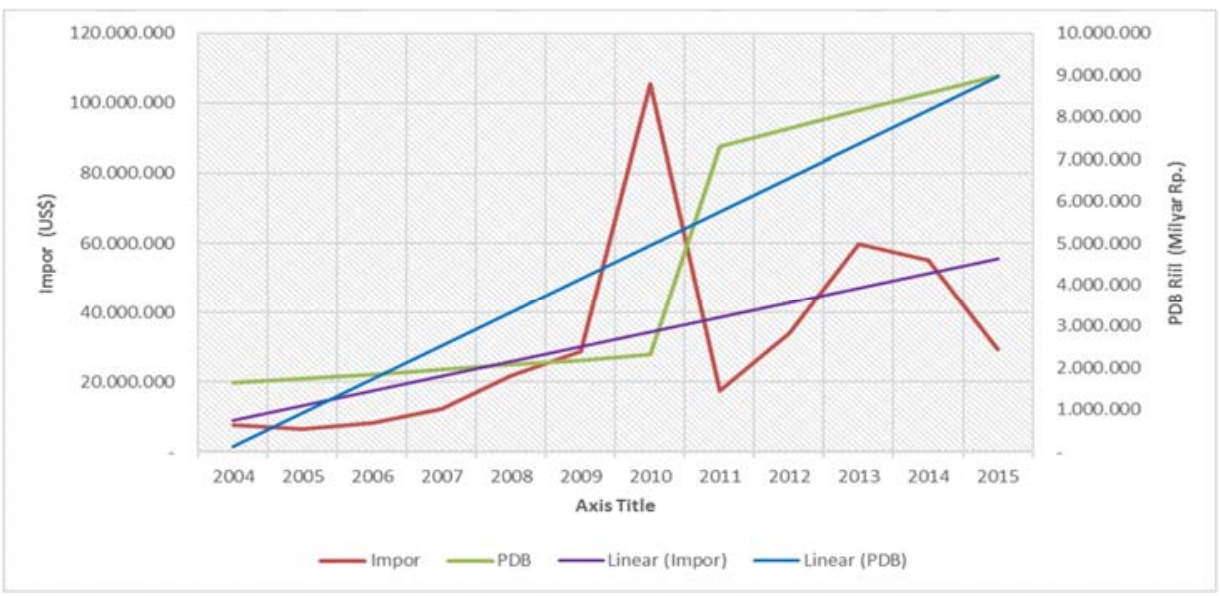

Gambar 3 Grafik fungsi PDB riil terhadap jumlah impor baterai primer.

Pada Gambar 4, nilai tukar Rupiah terhadap dolar Amerika Serikat (US\$) tertinggi pada tahun 2015 dengan nilai kurs sebesar Rp.13.386. Pelemahan nilai rupiah, diikuti penurunan impor baterai primer yang signifikan pada tahun tersebut. Nilai tukar dan impor memiliki tren kenaikan linier yang sama dari tahun 20042010.

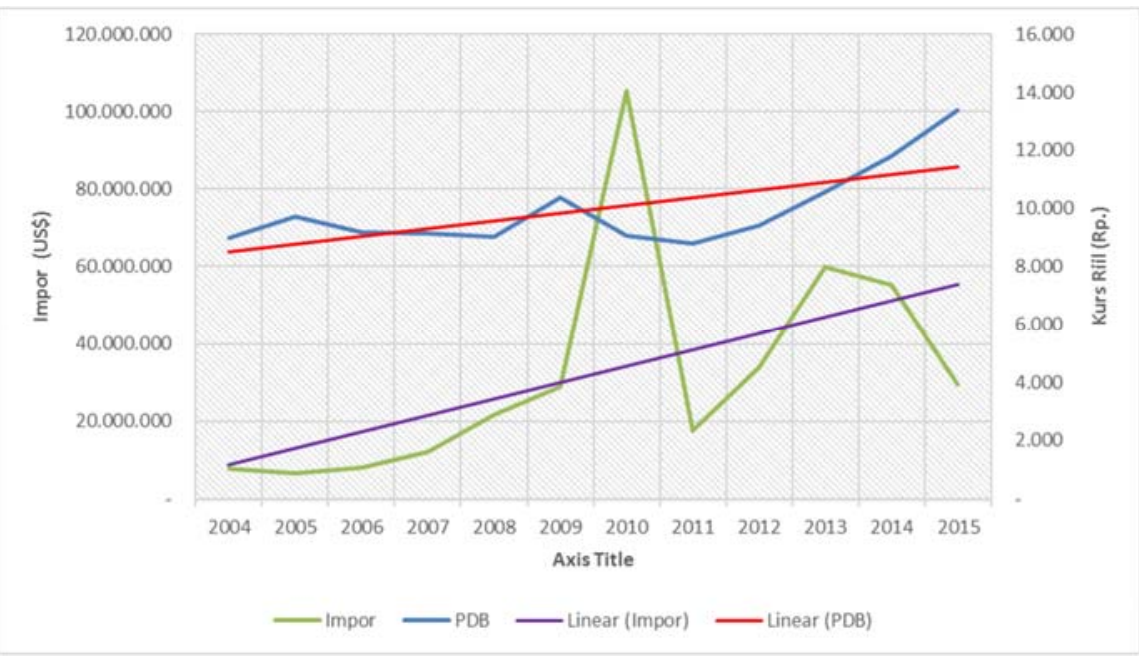

Gambar 4 Grafik fungsi kurs riil terhadap jumlah impor baterai primer.

Impor baterai primer pada tahun 2011 menurun sangat drastis, salah satu penyebabnya adalah karena adanya pemberlakuan SNI baterai primer secara wajib pada tahun 2010. Pada awal tahun pemberlakuan SNI secara wajib, industri masih dalam proses penyesuaian dalam memenuhi semua persyaratan regulasi tersebut sehingga mempengaruhi perdagangan (Susanto \& Mulyono, 2017). Namun setelah industri baterai primer dari luar negeri mampu memenuhi persyaratan SNI tersebut, tren impor kembali naik dengan rata-rata sebesar 7\% dari tahun 2011 sampai dengan tahun 2015. Nilai kenaikan yang cepat ini dikarenakan adaptasi yang cepat oleh industri dari luar negeri untuk memenuhi persyaratan regulasi (Prakosa, 2012).

Pemberlakuan SNI baterai primer secara wajib, mengharuskan produsen baterai primer dalam negeri dan luar negeri yang memasarkan produknya di wilayah Negara Kesatuan Republik Indonesia (NKRI), memenuhi persyaratan mutu yang ada dalam SNI 04-2051.1-2004 dan SNI 042051.2-2004 (Kementerian Perindustrian, 2009b); (Kementerian Perindustrian, 2009a). Pemenuhan 
persyaratan terhadap SNI tersebut, dibuktikan melalui Sertifikat Produk Penggunaan Tanda SNI (SPPT SNI) dari Lembaga Sertifikasi Produk (LSPro) yang ditunjuk oleh Kementerian Perindustrian.

\subsection{Analisis Ekonometri}

Tabel 3 Analisis ekonometri.

\begin{tabular}{lcll}
\multicolumn{1}{c}{ Variabel } & Koefisien & Prob. & \multicolumn{1}{c}{ Keterangan } \\
\hline Nilai_Tukar & -3.169285 & 0.0031 & Signifikan (-) \\
PDB & 2.545095 & 0.0018 & Signifikan (+) \\
Penerapan_SNI*Nilai_Tukar & 3.632237 & 0.0029 & Signifikan (+) \\
Penerapan_SNI*PDB & -2.512496 & 0.0029 & Signifikan (-) \\
Impor(-1) & 0.538973 & 0.0001 & Signifikan (+) \\
D(Penerapan_SNI) & -0.019524 & 0.9648 & Tidak Signifikan \\
Adjusted R-squared & & 0.776225 & \\
Prob(F-statistic) & & 0.000000 & \\
\hline
\end{tabular}

Untuk menentukan model matematis yang terbentuk dari variabel ekonomi dapat dianalisis menggunakan analisis ekonometrika (Khoiruroh \& Setiawan, 2014). Hasil analisis ekonometrika untuk mengetahui hubungan antara nilai tukar rupiah, PDB dan penerapan SNI baterai primer terhadap impor baterai primer disajikan pada Tabel 3.
Berdasarkan analisis ekonometrika pada Tabel 3, nilai koefisien determinasi (Adjusted R2) sebesar 0,776225 atau 77,62\% yang berarti variabel bebas yang terdiri dari nilai tukar rupiah, nilai PDB, dan variabel dummy penerapan wajib SNI baterai primer dapat menjelaskan variabel impor baterai primer sebesar $77,62 \%$, sedangkan sisanya $22,37 \%$ dipengaruhi oleh faktor lain. Model regresi ini memiliki nilai Prob (F-statistic) sebesar 0,000000 (kurang dari 0,05), sehingga model ini signifikan dan mampu menjelaskan perilaku impor baterai primer selama priode 2004-2015.

Variabel nilai tukar rupiah (kurs) riil secara parsial berpengaruh signifikan dan berkorelasi negatif terhadap nilai impor baterai primer. Koefisien nilai tukar rupiah sebesar 3,169285 mempunyai makna bahwa setiap kenaikan nilai tukar riil 1\%, maka jumlah impor baterai primer akan turun sebesar $3,169285 \%$. Hal ini sama dengan penelitian Prakosa (2012), yang menyampaikan bahwa nilai tukar rupiah berpengaruh negatif terhadap impor ban mobil.

Variabel nilai PDB secara parsial berpengaruh signifikan dan berkorelasi positif terhadap nilai impor baterai primer. Koefisien PDB sebesar 2,545095 mempunyai makna bahwa setiap kenaikan PDB sebesar $1 \%$, maka jumlah impor baterai primer akan naik sebesar $2,545095 \%$. Kondisi ini sama dengan penelitian dari Mardianto \& Kusumajaya (2014), Setiyaningsih (2014), Prakosa (2012) dan Faisol (2017), yang menyatakan bahwa PDB berpengaruh signifikan secara positif terhadap impor. Berdasarkan nilai koefisien yang lebih dari 1, variabel nilai tukar rupiah dan PDB mempunyai sifat elastis yang berarti bahwa variabel nilai tukar rupiah dan PDB sangat mempengaruhi impor baterai primer.
Koefisien variabel impor (-1) atau (lag impor) sebesar 0,538973 berarti bahwa jumlah impor baterai primer pada periode sebelum berpengaruh signifikan secara positif terhadap jumlah impor baterai primer pada periode setelahnya. Besaran koefisien lag impor berarti bahwa kenaikan impor baterai primer pada periode sebelumnya sebesar $1 \%$, maka jumlah impor baterai primer pada periode selanjutnya akan naik sebesar 0,538973\%. Nilai koefisien ini juga berarti bahwa variabel lag impor memunyai sifat inelastis yang berarti bahwa variabel ini hanya memberikan sedikit pengaruh terhadap jumlah kenaikan impor baterai primer karena memiliki koefisien kurang dari 1.

Variabel penerapan SNI secara parsial tidak berpengaruh signifikan terhadap nilai impor baterai primer. Namun secara simultan dengan variabel nilai tukar, penerapan SNI berpengaruh signifikan secara positif. Sedangkan secara simultan dengan variabel PDB, variabel penerapan SNI berpengaruh signifikan secara negatif terhadap nilai impor baterai primer. Hal ini juga terlihat dari nilai koefisien penerapan SNI sebesar -0,019524 yang bersifat inelastis yang berarti bahwa variabel ini secara parsial hanya memberikan sangat sedikit pengaruh terhadap jumlah kenaikan impor baterai primer.

Hasill penelitian ini berbeda dengan hasil penelitian dari Prakosa (2012) yang menyampaikan bahwa pemberlakuan wajib SNI ban mempunyai hubungan yang signifikan positif dengan impor ban secara parsial. Sedangkan secara simultan dengan variabel lain berpengaruh signifikan positif terhadap impor ban. Shoim \& Lubis (2014), juga menyampaikan bahwa pemberlakuan SNI besi beton secara wajib berdampak negatif terhadap impor besi beton periode tahun 2002 sampai dengan 2011. 


\section{KESIMPULAN}

Variabel penerapan SNI secara parsial tidak berpengaruh signifikan terhadap nilai impor baterai primer. Namun secara simultan dengan variabel nilai tukar, penerapan SNI berpengaruh signifikan secara positif. Sedangkan secara simultan dengan variabel PDB, variabel penerapan SNI berpengaruh signifikan secara negatif terhadap nilai impor baterai primer. Penerapan wajib SNI baterai primer tidak memberikan hambatan maupun peluang pada perdagangan impor baterai primer Indonesia, hal ini karena melalui skema pemberlakuan wajib baterai primer maka kualitas baterai primer yang beredar di Indonesia sudah memiliki persyaratan minimal (minimum requirements) yang sama, yaitu Standar Nasional Indonesia (SNI), sehingga konsumen sudah percaya akan kualitas dan kurang memperdulikan asal suatu produk, baik impor maupun dalam negeri. Selain itu, pangsa pasar baterai primer sebagian besar dikuasai oleh industri dalam negeri, sehingga tidak bergantung pada produk impor yang menyebabkan permintaan impor baterai primer tidak tinggi atau meningkat secara signifikan.

\section{UCAPAN TERIMA KASIH}

Ucapan terima kasih kami sampaikan kepada Bapak Teguh Prakoso dan Bapak Mukhammad Hisyam yang telah mendukung dan memberikan masukan pada penelitian ini. Ucapan terima kasih juga kami sampaikan kepada anggota tim peneliti dan pihak-pihak yang mendukung penelitian ini.

\section{DAFTAR PUSTAKA}

Atmadji, E. (2009). Analisis Impor Indonesia. Jurnal Ekonomi Pembangunan, 9(1), 3346.

Badan Standardisasi Nasional. SNI 04-2051.22004 Baterai Primer - Bagian 2: Spesifikasi Fisik dan Listrik (2004). Indonesia.

Bank Indonesia. (2016). Metadata: Informasi Dasar Produk Demestik Brotu (PDB).

Blind, K., \& Mangelsdorf, A. (2016). Motives to standardize: Empirical evidence from Germany. Technovation, 48-49, 13-24. http://doi.org/https://doi.org/10.1016/j.tec hnovation.2016.01.001

Christianto, E. (2013). Faktor yang Memengaruhi Volume Impor Beras di Indonesia. Jurnal JIBEKA, 7(2), 38-43.

D. N. Gujarati. (2004). Basic Econometric. New York: Mc Graw-Hill.
Dwijayanthy, F., \& Naomi, P. (2010). Analisis Pengaruh Inflasi, BI Rate, dan Nilai Tukar Mata Uang terhadap Profitabilitas Bank Periode 2003 - 2007. Jurnal Karisma, 3(2), 87-98.

Faisol, N. F. (2017). Pengaruh Pertumbuhan Produk Domestik Bruto (PDB), Laju Inflasi dan Nilai Tukar Rupiah terhadap Nilai Impor Indonesia. In Prosiding Pluralisme Dalam Ekonomi dan Pendidikan (pp. 189-200). Retrieved from http://ekp.fe.um.ac.id/wpcontent/uploads/2017/06/17.-NazarudinFahmi.pdf

Freimuth, C., Oelmann, M., \& Amann, E. (2018). Development and prospects of standardization in the German municipal wastewater sector. Science of The Total Environment, 635, 375-389. http://doi.org/https://doi.org/10.1016/j.scit otenv.2018.03.347

Ginting, A. M. (2013). Pengaruh Nilai Tukar Terkadap Ekspor Indonesia. Buletin Ilmiah Litbang Perdagangan, 7(1), 1-17. http://doi.org/http://dx.doi.org/10.30908/bi Ip.v7i1.96

Handayani, R. (2013). Pengantar Ekonometrika (Vol. 53).

Husman, J. A. (2005). Pengaruh Nilai Tukar Riil Terhadap Neraca Perdagangan Bilateral Indonesia: Kondisi Marshall-Lernerdan Fenomena J-curve. Buletin Ekonomi Moneter Dan Perbankan, 8(3), 1-26. http://doi.org/https://doi.org/10.21098/be mp.v8i3.141

Ing, L. Y. (2015). Free Trade Agreements for Indonesia? Retrieved August 1, 2018, from

https://thediplomat.com/2015/04/freetrade-agreements-for-indonesia/

Intriligator, M. D. (1978). Econometric Models, Techniques, \& Applications. New Jersey: Prentice Hall Inc.

Kementerian Perdagangan. (2011). Kajian dampak kesepakatan perdagangan bebas terhadap daya saing produk manufaktur Indonesia. Jakarta. Retrieved from

http://www.kemendag.go.id/files/pdf/2014 /01/06/Full-Report-Kajian-Manufaktur.pdf

Kementerian Perdagangan. (2015). Perkembangan free trade agreement di dunia. Retrieved August 1, 2018, from http://ditjenppi.kemendag.go.id/

Kementerian Perindustrian. Peraturan Menteri Perindustrian Republik Indonesia Nomor 101/M-IND/PER/10/2009 Tentang Perubahan Peraturan Menteri 
Perindustrian Nomor 36/MIND/PER/10/2009 tentang Pemberlakuan Standar Nasional Indonesia (SNI) Secara Wajib (2009). Indonesia.

Kementerian Perindustrian. Peraturan Menteri Perindustrian Republik Indonesia Nomor 36/M-IND/PER/3/2009 Tentang Pemberlakuan Standar Nasional Indonesia (SNI) Secara Wajib (2009). Indonesia.

Kho, D. (2015). Pengertian Baterai dan JenisJenisnya. Retrieved August 1, 2018, from https://teknikelektronika.com/pengertianbaterai-jenis-jenis-baterai/

Khoiruroh, A. F., \& Setiawan. (2014). Analisis Ekonometrika Model Pendapatan Nasional Indonesia dengan Pendekatan Persamaan Sistem Simultan. Jurnal Sains Dan Seni Pomits, 3(2), 200-205. http://doi.org/10.12962/j23373520.v3i2.8 135

Mardianto, A., \& Kusumajaya, I. W. W. (2014). Pengaruh Inflasi, Cadangan Devisa, Dan Produk Domestik Bruto Terhadap Impor Barang Modal. E-Jurnal Ekonomi Pembangunan Universitas Udayana, 3(9), 395-430. Retrieved from https://ojs.unud.ac.id/index.php/eep/articl e/view/9313

McEachern, W. (2000). Ekonomi Makro: Pendekatan Kontemporer. Jakarta: Salemba Empat.

OECD. (2015). OECD Overview Indonesia 2015.

Prakosa, T. (2012). Pengaruh Permberlakuan Wajib Standar Nasional Indonesia (SNI) Ban Mobil Penumpang dan Truk Ringan Terhadap Impor Ban Mobil Penumpang dan Truk Ringan Indonesia. Universitas Indonesia. Retrieved from http://lib.ui.ac.id/file?file=pdf/abstrak/id_a bstrak-20301417.pdf
Satriady, A., Alamsyah, W., Saad, A. H. I., \& Hidayat, S. (2016). Pengaruh Luas Elektroda Terhadap Kartakteristik Baterai LiFePO 4. Jurnal Material Dan Energi Indonesa, 06(02), 43-48. Retrieved from http://jurnal.unpad.ac.id/jmei/article/view/ 10959/5163

Setiyaningsih, N. (2014). Pengaruh PDB, Inflasi, Tingkat Suku Bunga, Nilai Tukar terhadap Ekspor dan Impor Indonesia Periode 2004 - 2012. Sekolah Tinggi IImu Ekonomi Indonesia. Retrieved from http://repository.stiesia.ac.id/339/

Shoim, A., \& Lubis, A. F. (2014). Pengaruh Pemberlakuan Kebijakan Standar Nasional Indonesia (SNI) Secara Wajib Terhadap Impor dan Produksi dalam Negeri Pada Produk Besi Beton. Jurnal Kebijakan Ekonomi, 10(1). http://doi.org/http://dx.doi.org/10.21002/jk e.v10i1.138

Simorangkir, I., \& Suseno. (2004). Sistem dan Kebijakan Nilai Tukar. Seri Kebanksentralan.

Sugiyanto, C. (2007). Modul 1 Ekonometri, (Modul 1), 1-30.

Susanto, D. A., \& Mulyono, A. B. (2017). Efektifitas Penerapan SNI 2547:2008 Spesifikasi Meter Air Secara Wajib. Jurnal Standardisasi, 19(2), 90-102. http://doi.org/http://dx.doi.org/10.31153/js .v19i2.457

Tassey, G. (2000). Standardization in technology-based markets. Research Policy, 29(4), 587-602. http://doi.org/https://doi.org/10.1016/S00 48-7333(99)00091-8

Widyasanti, A. A. (2010). Perdagangan Bebas Regional Dan Daya Saing Ekspor. Buletin Ekonomi Moneter Dan Perbankan, 5-22. http://doi.org/10.21098/bemp.v13i1.251 
Jurnal Standardisasi Volume 21 Nomor 2, Juli 2019: Hal 91 - 100 